\title{
Factors that Influence Undergraduate University Desertion According to Students Perspective
}

\author{
Mayra Alban ${ }^{\# 1}$, David Mauricio ${ }^{* 2}$ \\ \# Faculty of Engineering in Computer Sciences \\ Technical University of Cotopaxi, Latacunga, Ecuador \\ ${ }^{1}$ mayra.alban@utc.edu.ec \\ * Faculty in Systems Engineering and Computer Sciences \\ National University of San Marcos, Lima, Perú \\ 22dmauricos@unmsm.edu.ec
}

\begin{abstract}
University desertion is defined as a withdrawal from the academic system that has a negative impact on the economic and social environment. Desertion is influenced by internal and external factors that affect students, institutions, and governments. A literature review shows empirical evidence concerning research conducted to solve the desertion problem. However, most of the studies we analyzed do not consider students' perceptions, which are a key factor in college dropout rates. For this reason, we propose some new factors that influence university desertion. These factors are supported by a study of 65 organizational and educational theories. To examine the influence of these factors, a case study was conducted with 3773 students at a public university in Ecuador. Logistic regression was used to determine the causal relationship between the identified factors and the students' university desertion. As a result, we established that when all the identified factors are present at the same time, the probability of a student deciding to drop out of college is $95 \%$ your paper to be published in the conference proceedings, you must use this document as both an instruction set and as a template into which you can type your own text. If your paper does not conform to the required format, you will be asked to fix it.
\end{abstract}

Keyword-Educational data mining, logistic regression, university desertion, desertion factors

\section{INTRODUCTION}

University desertion is a problem that affects most higher education institutions around the world. This topic generates controversy among administrators, professors, and students [1]. Today, high dropout rates are considered a possible deficiency of the undergraduate education system [2].

This can be seen from the academic and administrative indicators presented by management personnel at universities and higher education control agencies. In 2016, the dropout rate in India was 15.9\% [3], while in Belgium, it was $26.9 \%$; in the UnitedStates, the desertion rate for first and second year students was $44.8 \%$ [4], and in Costa Rica, it reached up to $49 \%$. According to the United Nations (UN), the 2016 university desertion rate was $40 \%$ in several Latin-American countries, such as Colombia and Ecuador, and was approximately 54\% in Brazil.

University desertion is influenced by a set of interacting factors that have a negative impact on students' decisions to drop out of college [5]. A literature review allows us to identify several studies related to factors that influence desertion. Nevertheless, these studies do not consider students' perspectives, which play a key role in university desertion. Consequently, the following study is based on organizational and educational theories and proposes 11 new factors that affect university desertion while taking students' perspectives into consideration. To examine the influence of these factors, an empirical study is performed with 3773 students.

This article is organized into six sections. In section two, the literature review is presented. The methodology applied in this research is described in section three. Sections four and five detail the experimental process and discuss the results, respectively. Finally, in section six, we state our conclusions.

\section{LITERATURE REVIEW}

University desertion can be defined as the cessation of an academic process and the non-completion of a formative process in higher education [6]. It is a problem that worries governments and has become a weakness in university education due to its high rates, which have negative effects on students and on the economic growth of societies [7]. Specifically, a university deserter is a student who has not exhibited academic activity for two consecutive semesters [6]. According to Stratton et al. [8], most studies related to university desertion indicate that once a student drops out of college, he/she will never resume his/her studies. Hence, university desertion is considered a permanent condition. 
University desertion is multifactorial [9]. It comprises academic, personal, social, institutional and economic dimensions, as proposed by Sánchez [10]. These factors have a significant impact on the probability of desertion because, in many cases, they impose external restrictions on students that compromise their ability to complete their undergraduate studies [11].The literature review presents empirical and theoretical evidence. Additionally, it aims to identify the factors that influence desertion. Tables I through V enumerate 112 factors that affect university desertion in students. These factors are classified into five dimensions.

TABLE I. Factors of the Personal Dimension

\begin{tabular}{|l|l|}
\hline \multicolumn{1}{|c|}{ Factors } & \multicolumn{1}{|c|}{ References } \\
\hline Adjustment & {$[12]$} \\
\hline Age & {$[4],[5],[8],[15],[16],[17],[18],[19],[20],[21]$,} \\
& {$[22],[23],[24],[25],[26],[27],[28],[29],[30],[31]$} \\
\hline Change of goal & {$[12],[32]$} \\
\hline Choice to change to current major & {$[24]$} \\
\hline Country or city of origin & {$[13],[26],[33]$} \\
\hline Domicile & {$[12],[16],[17],[18],[30],[34]$} \\
\hline Encouragement and support of parents & {$[27]$} \\
\hline Engagement of student & {$[5],[35],[36]$} \\
\hline Engagement of student & {$[5],[35]$} \\
\hline Ethnicity & {$[4],[13],[16],[17],[21],[22],[24],[25],[27],[28],[37],[38]$} \\
\hline Gender & {$[5],[4],[15],[16],[17],[18],[20],[21],[22],[23]$,} \\
\hline Has a computer & {$[24],[25],[26],[31],[33],[34],[39],[40],[42],[43][44],[45],[46]$} \\
\hline Health problem & {$[25]$} \\
\hline Interest level in current major & {$[32]$} \\
\hline Intrinsic motivation & {$[24]$} \\
\hline Leadership & {$[36],[47]$} \\
\hline Level on commitment & {$[45]$} \\
\hline Living on campus & {$[48]$} \\
\hline Loneliness & {$[22]$} \\
\hline Marital status & {$[49]$} \\
\hline Measure of student persistence & {$[8],[25],[26],[39],[44],[55]$} \\
\hline Pessimism & {$[50]$} \\
\hline Residency & {$[19],[46]$} \\
\hline Self-efficacy & {$[17],[22],[43]$} \\
\hline Student satisfaction & {$[15],[33],[36],[47]$,} \\
\hline Tuition fee source & {$[18],[32],[49],[51]$} \\
\hline Vocational involvement & {$[17]$} \\
\hline Work experience & {$[52]$} \\
\hline Year of birth & {$[43]$} \\
\hline & {$[41]$} \\
\hline
\end{tabular}

TABLE II. Factors of the Institutional Dimension

\begin{tabular}{|l|l|}
\hline \multicolumn{1}{|c|}{ Factors } & \multicolumn{1}{c|}{ References } \\
\hline Campus environment & {$[12]$} \\
\hline High school type & {$[13]$} \\
\hline Institutional involvement & {$[14]$} \\
\hline Infrastructure of university & {$[12]$} \\
\hline
\end{tabular}


TABLE IIII. Factors of the Economic Dimension

\begin{tabular}{|l|l|}
\hline \multicolumn{1}{|c|}{ Factor } & \multicolumn{1}{c|}{ Reference } \\
\hline Awarded scholarship & {$[33],[37],[55]$} \\
\hline Below poverty line & {$[39]$} \\
\hline Campus employment & {$[22]$} \\
\hline Dependency & {$[27]$} \\
\hline Fall student loan & {$[37]$} \\
\hline Family income & {$[25]$} \\
\hline Father's job & {$[56]$} \\
\hline Financial concerns & {$[36],[38]$} \\
\hline Financial need & {$[55]$} \\
\hline Investment & {$[48]$} \\
\hline Loan received & {$[37],[55],[60]$} \\
\hline Student employment status & {$[45]$} \\
\hline Student fee status & {$[29]$} \\
\hline Type of financial assistance & {$[24],[37],[42],[60]$} \\
\hline
\end{tabular}

TABLE IIIV. Factors of the Academic Dimension

\begin{tabular}{|l|l|}
\hline \multicolumn{1}{|c|}{ Factors } & \multicolumn{1}{|c|}{ References } \\
\hline Absenteeism & {$[45]$} \\
\hline Academic ability & {$[17],[30]$} \\
\hline Academic overload & {$[30]$} \\
\hline Academic performance & {$[31],[53],[55]$} \\
\hline Age at admission & {$[54]$} \\
\hline Average formative assessment result & {$[17]$} \\
\hline Best test score GPA, SAT & {$[4],[13],[18],[21],[22],[24],[34],[35],[37],[38]$,} \\
& {$[48],[49],[50],[55],[56],[57],[58],[59],[60]$} \\
\hline Cohort & {$[4],[16],[28],[40]$} \\
\hline Curricular involvement & {$[25]$} \\
\hline Degree & {$[16],[21],[41],[44],[55],[60]$} \\
\hline Degree aspiration & {$[38]$} \\
\hline Degree program length & {$[29]$} \\
\hline Educational goal & {$[5]$} \\
\hline English language literacy & {$[43]$} \\
\hline Enrolled in another institution & {$[32]$} \\
\hline Entry qualifications & {$[16],[50]$} \\
\hline Experience & {$[15],[16]$} \\
\hline Final examination test & {$[17],[45],[54],[58],[61],[62]$} \\
\hline First and second midterm exam grades & {$[54]$} \\
\hline First semester credit load & {$[22]$} \\
\hline Number quiz & {$[54]$} \\
\hline Participate in extracurricular activities & {$[12],[32]$} \\
\hline Points from secondary school & {$[24],[44],[45]$} \\
\hline Progression outcome & {$[16]$} \\
\hline Readiness & {$[15]$} \\
\hline Recognized credits & {$[17],[26],[53]$} \\
\hline Resource use & {$[52]$} \\
\hline Satisfaction with major & {$[12]$} \\
\hline Score of academic integration & {$[21],[54],[60]$} \\
\hline & \\
\hline
\end{tabular}




\begin{tabular}{|l|l|}
\hline Scores & {$[26],[27],[31],[33],[42],[54]$} \\
\hline Self-evaluation & {$[25],[45]$} \\
\hline
\end{tabular}

TABLE V. Factors of the Social Dimension

\begin{tabular}{|l|l|}
\hline \multicolumn{1}{|c|}{ Factors } & \multicolumn{1}{c|}{ References } \\
\hline Campus accommodation & {$[27],[29],[38]$} \\
\hline Belonging to a marginalized or vulnerable section of society & {$[28],[39]$} \\
\hline College status & {$[18]$} \\
\hline Community support & {$[45]$} \\
\hline Employment status & {$[24],[25],[39],[41]$} \\
\hline Family problems & {$[12]$} \\
\hline Father`s education level & {$[5],[21],[25],[26],[44],[56]$} \\
\hline Means of transportation & {$[25]$} \\
\hline Migrated before & {$[5],[40]$} \\
\hline Mother completed junior year & {$[40]$} \\
\hline Mother`s education level & {$[5],[21],[25],[31],[44],[45],[56]$} \\
\hline Occupation & {$[4],[26]$} \\
\hline Parent occupation & {$[32]$} \\
\hline Political status & {$[17]$} \\
\hline Social status & {$[20],[26],[27],[29],[44],[52]$} \\
\hline
\end{tabular}

\section{NEWLY IDENTIFIED FACTORS}

The set of new factors was built based on the literature review, 65 organizational theories, 12 educational theories and logical reasoning. As a result, 11 factors were obtained, which are described as follows:

F1: limited knowledge about specialized software usage in the university major refers to the student's ability to use specialized software for academic purposes. This type of software is designed with the goal of improving students' knowledge via the application of technology. It is not related to didactic multimedia material, virtual environments, the internet, blogs, wikis, forums, chat rooms, or messaging services. It is important to analyze the influence of this factor because students need to have adequate knowledge in the use of technologies that are applied in the process of their university education.

Software usage applied to the teaching process facilitates understanding and is often needed for specialized fields. For example, in the context of a computer science degree, the usage of technology such as PHP, Java, SQL, and MySQL is necessary for the development of informationsystems. If a student cannot use subjectspecific technology as part of the academic training process, he/she may lose motivation, stop attending academic activities and lose control of his/her grades and learning in that subject.

On the other hand, when a student is motivated, he/she will show an interest in learning and in activities that foster academic development (theory of motivation [63]).

Hypothesis H1: limited knowledge about the usage of specialized software in an undergraduate degree program influences university desertion.

F2:planned and unplanned pregnancy refers to the gestational process of a student during a university academic period. During adolescence, pregnancy is considered a biomedical problem with a high risk of complications [64]. Moreover, it has socio-cultural and psychological implications that affect the student at the personal, educational, family and social levels [65].

Most pregnant students are forced to drop out of college, which limits their study and work opportunities and endangers their living conditions. Young parenthood, especially in the teenage years, generates multiple disadvantages in terms of the achievement of academic objectives [66]. This problem is accentuated in universities due to higher academic requirements that demand more attention. 


\section{Hypothesis H2: planned and unplanned pregnancy influences university desertion.}

F3: teacher's commitment to the student refers to the principles a teacher expresses for the academic and human development of the students. An understanding of teaching competencies communicates the student's potential to engage in the teacher's work with initiative, flexibility, and autonomy [67]. This factor is relevant to students' university desertion because the integration of knowledge, abilities, motivation, and values, when expressed through effective teaching, ethics and social commitment, motivates students to continue their studies. Tutoring and mentoring programs at universities acknowledge the importance of this factor in reducing dropout rates. Furthermore, competent professionals who possess knowledge and abilities that enable successful performances in their specific disciplines (Gestalt theory [68]) will also empower human and academic development in their students. They motivate them to reach favorable outcomes in terms of university completion.

Hypothesis H3: the teacher's commitment to the student influences university desertion.

F4: a first-born son's financial commitment to his family refers to an obligation acquired by the eldest son in afamily when he assumes financial responsibility for the family due to his father's absence [69]. This factor is relevant to university desertion because the order of birth among children affects their academic development as students [70].

This is especially true when older children need to drop out of their university studies to work and financially support their siblings. It should be noted that people feel motivated when they satisfy their highest-priority needs before pursuing professional growth (Maslow's theory [71]). Consequently, if a student does not attend to basic family needs such as housing, health, and food, he will not be motivated to continue his undergraduate education and will decide to drop out of college.

Hypothesis H4: a first-born son's financial commitment to his family influences university desertion.

F5:bullying refers to an aggressive behavior pattern among students that involves repeated unwanted, negative actions [72]. This type of abuse constitutes physical and psychological persecution [73]. If a student is abused physically and emotionally, his/her learning process will be affected. This problem is widely studied at the high school level. However, it also causes major difficulties at universities because most students live alone without the care and protection of their parents, which makes it impossible for them to access early help to resolve the aggression.

Social ostracism and the necessity of leaving a hostile environment can lead to university desertion in students. Additionally, continued abusive relationships have negative effects on the victims, such as lack of selfesteem, anxiety and even depression (personality theory [74]).

Hypothesis H5: bullying influences university desertion.

F6:sexism refers to an attitude or way of thinking that considers men superior by nature to women or vice versa [75]. This factor is relevant to university desertion because sexist behavior among students can cause differences in gender roles.

This is especially true for university majors in which the female student population is significantly higher than the male student population or vice versa. As a result, negative relationships in the students' social environment can provoke the degradation of self-image for men and women on a social and academic level (based on the theory of socialization).

Hypothesis H6: sexism influences university desertion.

F7: student's acquired addictionsrefers to negative behaviors that are socially accepted among students. They have the common characteristic of providing immediate gratification; some examples are social networks, drugs, and video games. Addictions can occur when students are unable to maintain their relationships with friends or relatives during their professional training.

This situation provokes isolation and a sense of tedium that trigger an addiction to something. Human beings feel a deep need to establish relationships and connections(modeling and induction theory of mind, [76]). When the relationship between the student and the addiction is constant, it becomes problematic. In this situation, the student prioritizes the addictive activity instead of his/her academic obligations.

Hypothesis H7: students' addictions influence university desertion.

F8: students' number of children refers to the number of children students have during their university training. Fertility and reproduction among high school students is a constant problem that is closely connected to the desertion of the education system [77] because students with children need to spend time taking care of them and finding a way to financially support their family to meet basic needs for their children's welfare.

This problem is exacerbated in the university context because students have strict study schedules, which require more responsibility and time commitment to advance academically. 
Hypothesis H8: the number of children that students have influences university desertion.

F9: students' adaptation to university learning methodologies refers to the degree of adjustment a university student experiences in relation to the change in learning methods applied by teachers in the university context compared with the methods applied at the high school level. It is relevant to university desertion because university students have to be able to manage their knowledge, keep updated in terms of academic content, and select appropriate situations to develop professionally and adapt to changes.

Hypothesis H9: the students' adaptation to university learning methodologies influences university desertion.

F10: major or institution ranking refers to the position of a university or major in relation to other institutions or major. University rankings are presented in lists compiled by groups of institutions and are determined by indicators of quality [78]. This type of classification may have an impacton the university's prestige and influence the number of students enrolled and their quality [79].

If a student perceives his/her university to be prestigious, this perception will increase his/her interest in staying at theuniversity due to the possible increase in job opportunities, social status, academic benefits and student wellness. On the other hand, if students' interest decreases, they may leave the university and enroll at more suitable institutions.

Hypothesis H10: major and institution rankings influence university desertion.

F11: students' perspectives on their integration into the labor market refers to students' perceptions of the training and academic resources provided by the university to integrate students into the labor market. There is a close relationship between higher education and the employment world because universities provide students with knowledge, abilities, and competencies that increase their individual capacities to obtain jobs [80].

The link between education and employment can generate a positive or negative impact on students. It is believed that a higher education level results in greater success in the workforce, which leads to a better economic status and a higher level of social influence [81].

Hypothesis H11: students' perspectives on their integration into the labor market influence university desertion.

The model for determining new desertion factors includes a set of eleven factors that could be causes of university desertion (see Table VI and Fig. 1). 


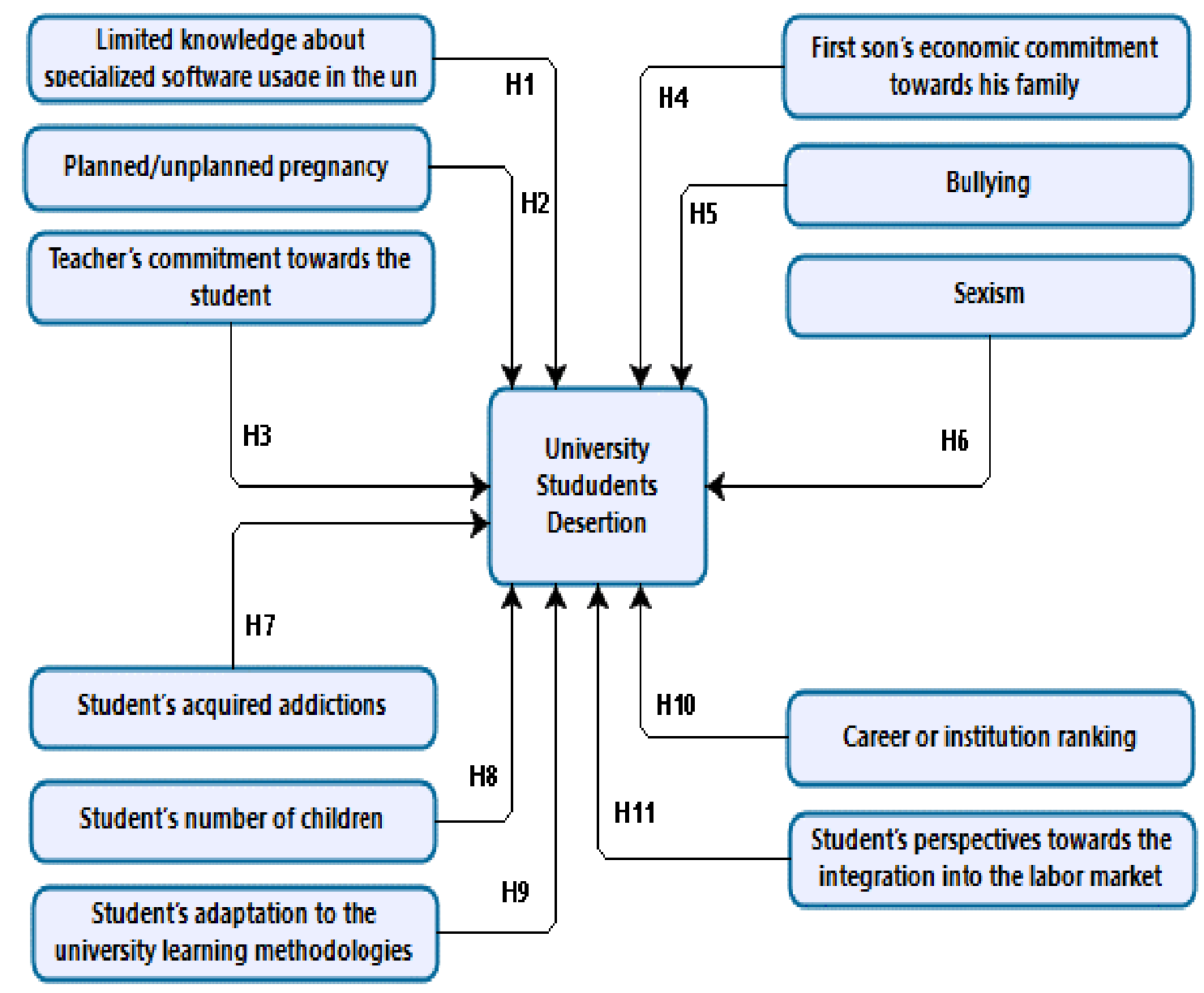

Fig. 1. Conceptual Model 
TABLE VIV. Newly Identified Factors in University Desertion

\begin{tabular}{|c|c|c|c|}
\hline ID & Factor & Description & Source \\
\hline F01 & $\begin{array}{l}\text { Limited knowledge about } \\
\text { specialized software usage in the } \\
\text { university major }\end{array}$ & $\begin{array}{l}\text { Student's ability to use specialized } \\
\text { software for academic purposes }\end{array}$ & $\begin{array}{l}\text { Theory of } \\
\text { motivation [63] }\end{array}$ \\
\hline F02 & Planned and unplanned pregnancy & $\begin{array}{l}\text { Student's gestation process during her } \\
\text { university education }\end{array}$ & {$[64,66]$} \\
\hline F03 & $\begin{array}{l}\text { Teacher's commitment to the } \\
\text { student }\end{array}$ & $\begin{array}{l}\text { Set of principles that the teacher expresses } \\
\text { for the academic and human development } \\
\text { of the students }\end{array}$ & $\begin{array}{l}\text { Gestalt theory } \\
{[68]}\end{array}$ \\
\hline F04 & $\begin{array}{l}\text { First-born son's financial } \\
\text { commitment to his family }\end{array}$ & $\begin{array}{l}\text { The obligation acquired by the oldest son } \\
\text { in a family due to the father's absence. He } \\
\text { takes on financial responsibility for the } \\
\text { household [69] }\end{array}$ & $\begin{array}{l}\text { Maslow's theory } \\
\text { [71] }\end{array}$ \\
\hline F05 & Bullying & $\begin{array}{l}\text { Physical, verbal and psychological } \\
\text { aggression with the intent of harming } \\
\text { another person [72] }\end{array}$ & $\begin{array}{l}\text { Personality } \\
\text { theory [74] }\end{array}$ \\
\hline F06 & Sexism & $\begin{array}{l}\text { Attitude or way of thinking that affirms } \\
\text { that men are by nature superior to women } \\
\text { or that women are by nature superior to } \\
\text { men [75] }\end{array}$ & {$[75]$} \\
\hline F07 & Students' acquired addictions & $\begin{array}{l}\text { Student behaviors that are socially } \\
\text { accepted and have the common } \\
\text { characteristic of providing immediate } \\
\text { gratification, such as social networking, } \\
\text { drugs, or video games. }\end{array}$ & {$[76]$} \\
\hline F08 & Student's number of children & $\begin{array}{l}\text { Number of children a student has during } \\
\text { his/her university education. }\end{array}$ & {$[77]$} \\
\hline F09 & $\begin{array}{l}\text { Student's adaptation to the } \\
\text { university learning }\end{array}$ & $\begin{array}{l}\text { Level of adjustment a university student } \\
\text { has to changes in the learning methods } \\
\text { applied by the teachers in a university } \\
\text { context which are different from the ones } \\
\text { applied in high school }\end{array}$ & \\
\hline F10 & Major or institution ranking & $\begin{array}{l}\text { Position of a university or major in relation } \\
\text { to other universities or majors [78]. }\end{array}$ & [79] \\
\hline F11 & $\begin{array}{l}\text { Student's perspective on his or her } \\
\text { integration into the labor market }\end{array}$ & $\begin{array}{l}\text { Idea or projection a student has about the } \\
\text { learning and academic resources provided } \\
\text { by the university toward integration into } \\
\text { the workforce }\end{array}$ & {$[80,81]$} \\
\hline
\end{tabular}

\section{METHOD}

\section{A. Information Gathering}

A survey was administered using Google Forms for more than three months, starting in June until October 2017. The survey was offered to undergraduate students in the public's universities in, Ecuador who had enrolled between March 2012 and October 2017. A total of 3773 students answered the survey.

The survey's objective was to determine the students' points of view regarding the possible causes of university desertion. The survey consisted of 3 sections. Section 1 collected information related to the institution and characterizations of the students (10 questions), section 2 contained questions about the factors that influence desertion (13 questions), and section 3 contained additional questions to complement the study (7 questions).

The results for section 2 were evaluated using a Likert scale of 5 points, which are as follows: 1: not influential, 2: slightly influential, 3: moderately influential, 4: highly influential, and 5: totally influential. To validate the survey questions, two pilot tests were established. The first was directed at people with experience in topics related to university desertion and was administered to a sample of 200 students. The objective was to verify arelationship between the questions and the hypotheses. As a result of this test, the wording of the original survey was corrected and the questions were rewritten using simple language that could be easily understood by the students. 


\section{B. Information Analysis}

This step is structured in three stages:

1. A descriptive analysis of the population is used to determine the demographic characteristics of the students.

2. Reliability testing and questionnaire validation. Cronbach's alpha was used to determine the internal consistency of the instrument and to ensure that the items measured using the Likert scale are highly correlated.

3. Data modelling using logistic regression based on the Box-Jenkins method.

\section{RESUlts AND Discussion}

\section{A. Descriptive Analysis of the Population}

Table VII displays a summary of the demographic characteristics for students enrolled in at public universities in Ecuador.

TABLE VIV. Descriptive Statistics

\begin{tabular}{|c|c|c|c|}
\hline Variable & Description & Value & Percentage \\
\hline \multirow{2}{*}{ Gender } & Male & 1745 & $46.25 \%$ \\
\hline & Female & 2028 & $53.75 \%$ \\
\hline \multirow{3}{*}{ Age Range } & Age $<20$ & 2171 & $57.54 \%$ \\
\hline & Age $21-28$ & 1494 & $39.60 \%$ \\
\hline & Age $>29$ & 108 & $2.86 \%$ \\
\hline \multirow{4}{*}{ Marital Status } & Married & 521 & $13.81 \%$ \\
\hline & Divorced & 33 & $0.87 \%$ \\
\hline & Single & 3032 & $80.36 \%$ \\
\hline & Non-married partnership & 187 & $4.96 \%$ \\
\hline \multirow{6}{*}{ Ethnicity } & Afro descendant & 6 & $0.16 \%$ \\
\hline & White & 19 & $0.50 \%$ \\
\hline & Indigenous & 142 & $3.76 \%$ \\
\hline & Mestizo & 3581 & $94.91 \%$ \\
\hline & Montubio & 11 & $0.29 \%$ \\
\hline & Mulatto & 13 & $0.34 \%$ \\
\hline \multirow{2}{*}{ Has a Job } & No & 2763 & $73.23 \%$ \\
\hline & Yes & 1010 & $26.77 \%$ \\
\hline \multirow{5}{*}{ Type of Household } & Mother and siblings & 599 & $15.88 \%$ \\
\hline & Father and siblings & 750 & $19.88 \%$ \\
\hline & Father, mother, and siblings & 1926 & $51.05 \%$ \\
\hline & Spouse and children & 303 & $8.03 \%$ \\
\hline & Other relatives & 195 & $5.17 \%$ \\
\hline \multirow{4}{*}{$\begin{array}{l}\text { Father's education } \\
\text { level }\end{array}$} & None & 362 & $9.59 \%$ \\
\hline & Elementary & 1816 & $48.13 \%$ \\
\hline & High school & 1147 & $30.40 \%$ \\
\hline & University & 448 & $11.87 \%$ \\
\hline \multirow{4}{*}{$\begin{array}{l}\text { Mother's education } \\
\text { level }\end{array}$} & None & 336 & $8.91 \%$ \\
\hline & Elementary & 1889 & $50.07 \%$ \\
\hline & High school & 1177 & $31.20 \%$ \\
\hline & University & 371 & $9.83 \%$ \\
\hline
\end{tabular}

The information corresponds to panel data; information for students pursuing graduate degrees was not considered.

The results obtained from this socio-economic inquiry allows determining significant differences in the used data for the study. For example, the female population is higher, students often come from households where their father or mother is absent or live with other relatives, the predominant education level of the students' parentsiselementary school and a high percentage of students work while pursuing university degrees. 


\section{B. Data Reliability}

Cronbach's alpha coefficient was utilized. The variance method was utilized to determine the internal consistency index for the survey. The results were obtained using SPSS, and the value calculated was 0.908, which indicates that the questionnaire was reliable.

TABLE VVIII. Survey's Validity Result

\begin{tabular}{|c|c|}
\hline \multicolumn{2}{|c|}{ Reliability statistics } \\
\hline Cronbach's alpha & Number of elements \\
\hline .908 & 37 \\
\hline
\end{tabular}

On the other hand, Table IX shows the Likert scale results for the survey given to the students regarding factors that influence university desertion. To analyze the answers, a mean value was established for the scores. Using the visual grouping method, between 1 and 5 interval cut points were obtained, which allowed the establishment of upper limits for the ranges.

TABLE VIIX. Results of the Likert Scale Evaluation

\begin{tabular}{|l|c|c|c|c|}
\hline \multicolumn{1}{|c|}{ Scale } & Frequency & \% & \% Valid & \% Cumulative \\
\hline Low influence & 14 & 0.4 & 0.4 & 0.4 \\
\hline Medium influence & 110 & 3.5 & 3.5 & 3.9 \\
\hline High influence & 1116 & 25.5 & 25.5 & 29.4 \\
\hline Total influence & 2533 & 70.6 & 70.6 & 100.0 \\
\hline Total & $\mathbf{3 7 7 3}$ & $\mathbf{1 0 0 . 0}$ & $\mathbf{1 0 0 . 0}$ & \\
\hline
\end{tabular}

Table X shows the calculation of the measures of central tendency, namely the median, mode and standard deviation, for the students' answers on their perceptions of desertion at higher education institutions. The mean, which is $>4$, indicates that there is a high correlation among the students' answers regarding desertion.

\section{Data Modelling}

To build the model, we utilized the Box-Jenkins method proposed by Gujarati \& Porter [82]. It comprises 4 stages: identification, estimation, verification, and forecasting. They are described below.

TABLE X. Measures of Central Tendency for Perceptions of University Desertion

\begin{tabular}{|c|c|c|c|}
\hline Hypothesis & Mean & Mode & Desv.tip \\
\hline H1 & 4.27 & 5 & 0.889 \\
\hline H2 & 4.28 & 5 & 1.004 \\
\hline H3 & 4.17 & 5 & 1.085 \\
\hline H4 & 4.35 & 5 & 1.042 \\
\hline H5 & 4.02 & 4 & 0.914 \\
\hline H6 & 4.03 & 4 & 1.022 \\
\hline H7 & 4.05 & 4 & 0.892 \\
\hline H8 & 4.25 & 5 & 1.078 \\
\hline H9 & 4.24 & 5 & 1.173 \\
\hline H10 & 4.21 & 5 & 1.138 \\
\hline H11 & 4.33 & 5 & 0.991 \\
\hline
\end{tabular}

Specification: the model has an independent variable vector $X=\left(F_{1}, F_{2} \ldots F_{n}\right)$ consisting of the factors that are considered to influence the $\mathrm{Y}$ result (desertion). We then use equation (1) proposed by Ibarra [83]:

$$
P(y=1 \mid x)=\frac{e^{B o+B i x}}{1}+e^{B o+B i x}(1)
$$

Where:

$B_{o}=$ independent term

$P=$ probability of an event

$Y=$ dependent variable

$\mathrm{X}=$ independent variables $(\mathrm{F})$

$B i x=$ combination of the independent variables 
Estimate: at this stage, the significance coefficients and correlation factors are estimated and presented in Table 10. Logistic regression was used because it is a non-linear parameter estimation method. It allows the prediction of probabilities given certain characteristics of the independent variables [83].

One of the characteristics of the logistic model is that the dependent variables should contain binary data; this means that the model can have two possible results:

$$
\begin{aligned}
& Y=1 \text { : High probability of influence for the identified desertion factors. } \\
& Y=0 \text { : Low probability of influence for the identified desertion factors. }
\end{aligned}
$$

The software program Eviews was used to determine the influence of the identified factors in university desertion. The results of the logistic regression model are presented in equation (2):

$$
\begin{gathered}
\mathrm{Y}=1-@ \mathrm{CLOGISTIC}(-(0.818043 * \mathrm{~F} 1+0.629028 * \mathrm{~F} 2-0.390826 * \mathrm{~F} 3+0.380309 * \mathrm{~F} 4- \\
0.809717 * \mathrm{~F} 5+0.852620 * \mathrm{~F} 6+0.687710 * \mathrm{~F} 7+1.384878 * \mathrm{~F} 8+0.281206 * \mathrm{~F} 9+0.637297 * \\
\mathrm{~F} 10+1.346561 * \mathrm{~F} 11-4.819381))
\end{gathered}
$$

Table XI displays the behavior of each factor and its positive $(+)$ or negative $(-)$ correlation with desertion. The value $P(\mathrm{Y}=1)=0.5$ served as critical point. The advantage of this method is that the hypothesis can be verified easily. The results show that the identified factors are statistically significant because the $\mathrm{p}$-value is $<$ 0.05. Consequently, these factors influence university student desertion.

Testing: after the parameter evaluation, it is important to conduct validation tests on the results to verify the quality of the sample information and the data stability within the specified model. At this stage, it is essential to point out whether divergences exist in the hypotheses since this may indicate an incorrect model specification.

TABLE XI. Significance Coefficients of the Factors

\begin{tabular}{|c|c|c|c|c|}
\hline Variable & Coefficient & Std. Error & z-Statistic & $P$-value \\
\hline C & -4.819 .381 & 0.356954 & 1.350 .141 & 0.00000 \\
\hline F1 & 0.818043 & 0.187763 & 4.356 .790 & 0.00000 \\
\hline F2 & 0.629028 & 0.180224 & 3.490 .262 & 0.00050 \\
\hline F3 & -0.390826 & 0.139217 & 2.807 .320 & 0.00400 \\
\hline F4 & 0.380309 & 0.172667 & 2.202 .562 & 0.02760 \\
\hline F5 & 0.809717 & 0.181720 & 4.455 .839 & 0.00000 \\
\hline F6 & 0.852620 & 0.152875 & 5.577 .225 & 0.00000 \\
\hline F7 & 0.687710 & 0.150909 & 4.557 .112 & 0.00000 \\
\hline F8 & 1.384 .878 & 0.160912 & 8.606 .428 & 0.00000 \\
\hline F9 & 0.281206 & 0.135480 & 2.075 .625 & 0.03790 \\
\hline F10 & 0.637297 & 0.143733 & 4.433 .882 & 0.00000 \\
\hline F11 & 1.346 .561 & 0.202286 & 6.656 .711 & 0.00000 \\
\hline
\end{tabular}

The OLS residues exhibited positive values above 0 and below 1 . These values validate $0<\mathrm{E}\left(\mathrm{Y}_{\mathrm{i}} \mid \mathrm{X}_{\mathrm{i}}\right) \geq 1$ and verify one of the principles of the logistic model (see Fig. 2). 


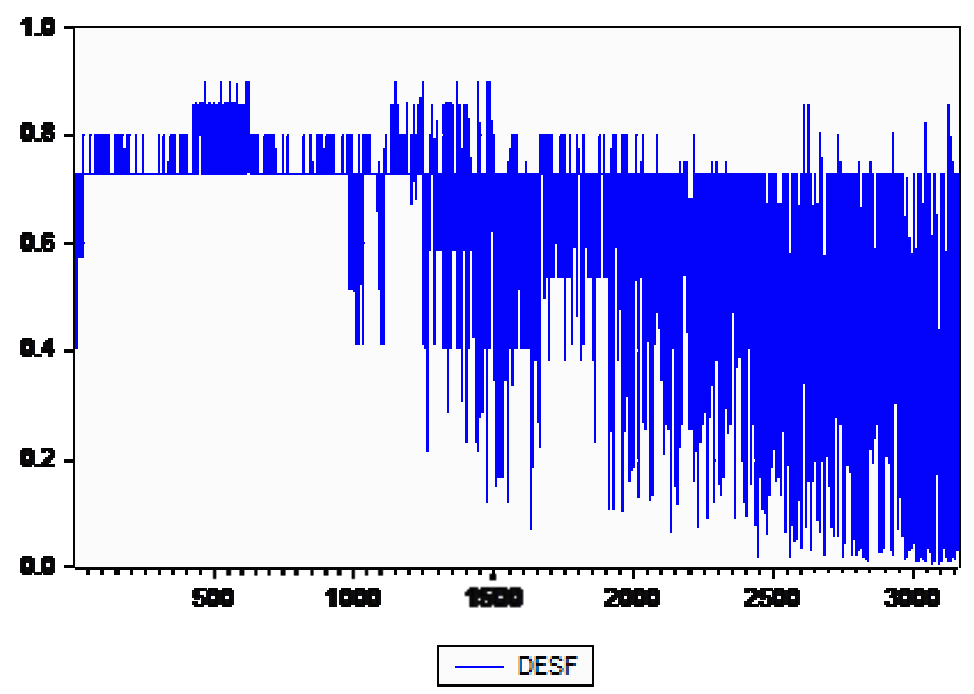

Fig. 2. OLS residues of the logistic regression model

The global contrast of the model was evaluated using the Pseudo- $\mathrm{R}^{2}$ McFadden index. The value of this statistic should be between 0 and 0.5 . The value we obtained from the model was 0.0133457 , which confirms that the model is statistically significant.

On the other hand, Hosmer-Lemershow tests were used to compare the predictions of the probabilities for theobserved data. These tests help indetermining if a model accurately describes the data and are based on the following hypotheses:

$$
\mathrm{Ha}_{0}=\text { the model represents a good data fit; }
$$

$\mathrm{Ha}_{1}=$ the model does not represent a good data fit.

TABLE XII. Hosmer-Lemershow Tests

\begin{tabular}{|c|c|c|c|}
\hline \multicolumn{4}{|c|}{ Goodness-of-Fit Evaluation for Binary Specification } \\
\hline \multicolumn{3}{|c|}{ Andrews and Hosmer-Lemeshow Tests } & \\
\hline \multicolumn{4}{|c|}{ Grouping based on predicted risk (randomized ties) } \\
\hline H-L Statistic & 2.86 & Prob. Chi-Sq(8) & 0.000 \\
\hline Andrews Statistic & 4.310 & Prob. Chi-Sq(10) & 0.000 \\
\hline
\end{tabular}

For Canary [84], the Hosmer-Lemershowstatistic indicates poor model adjustment if the significance value is greater than 0.15. According to our results, the alternative hypothesis $\left(\mathrm{Ha}_{1}\right)$ should rejected and the null hypothesis $\left(\mathrm{Ha}_{0}\right)$ accepted because Chi-Sq $=0.000$. Hence, the proposed model provides a good data fit and the variable $(\mathrm{X})$ of the model adequately estimates the probabilities. Wald's test of was used to verify the significance level and the estimates of the model parameter coefficients based on the following hypotheses:

$\mathrm{Hb}_{0=} \mathrm{X}$ does not influence desertion

$\mathrm{Hb}_{1}=\mathrm{X}$ influences desertion

TABLE XIII. Wald's Test

\begin{tabular}{|l|c|c|c|}
\hline Wald's Test: & & \\
\hline Equation: Logistic Model & \\
\hline Test Statistic & Value & Df & P-value \\
\hline F-statistic & 3.030 .830 & $(11,3150)$ & 0.000 \\
\hline Chi-square & 3.333 .913 & 11 & 0.000 \\
\hline $\begin{array}{l}\text { Null Hypothesis: } \\
\mathrm{C}(1)=\mathrm{C}(2)=\mathrm{C}(3)=\mathrm{C}(4)=\mathrm{C}(5)=\mathrm{C}(6)=\mathrm{C}(7)=\mathrm{C}(8)=\mathrm{C}(9)=\mathrm{C}(10)=\mathrm{C}(11)=0\end{array}$ \\
\hline
\end{tabular}


Since the $\mathrm{p}$-value is $<0.05, \mathrm{Hb}_{0}$ is rejected. Therefore, all the newly identified factors influence university desertion. To determine the probability of university desertion, an estimate of $\mathrm{Y}$ was calculated using the coefficients of maximum likelihood estimation, as shown in Table XIV. Additionally, a simulation process for the proposed model was generated using estimated $(\beta)$ values, the $\mathrm{X}$ values and the estimated $\mathrm{Y}$ values. For the variable $X$, entry values of 1 to 3 were used. For example, for the factor 1 , we used $X=1$ ( 1 child $), X 2=(2$ children) and $\mathrm{X}=3$ (3 children).

Since the logistic model is specified as $\mathrm{Y}$ (estimated) $=\ln (\mathrm{p} / 1-\mathrm{p})$ and the probability $(\mathrm{P})=\operatorname{Exp}(\mathrm{Y}$ estimated $) /[1+\operatorname{Exp}(Y$ estimated $)]$, the coefficients $(\beta)$ equal the logarithm of the probability. To calculate theantilogarithm or $\operatorname{Exp}(\beta)=\mathrm{P} /(1-\mathrm{P})$, we obtain the coefficients. Thus, increases in $(\beta)$ led to increases in the probability of university desertion.

The results obtained in the present study confirmed that the identified factors are statistically significant at a confidence level of $95 \%$ and a p-value of $0.05 \%$. Therefore, all of the newly identified factors influence university desertion.

TABLE XIV. Probabilities of Student University Desertion

\begin{tabular}{|c|c|c|c|c|}
\hline Factor & $(\beta)$ & Valor & Y(estimate) & $P$ \\
\hline \multirow{3}{*}{$\mathrm{F} 1$} & \multirow{3}{*}{0.818043} & $\mathrm{X}=1$ & 0.8180 & $69 \%$ \\
\hline & & $X=2$ & 1.6360 & $84 \%$ \\
\hline & & $X=3$ & 2.2660 & $92 \%$ \\
\hline \multirow{3}{*}{$\mathrm{F} 2$} & \multirow{3}{*}{0.629028} & $X=1$ & 0.6290 & $65 \%$ \\
\hline & & $X=2$ & 1.2580 & $78 \%$ \\
\hline & & $X=3$ & 1.8757 & $87 \%$ \\
\hline \multirow{3}{*}{ F3 } & \multirow{3}{*}{-0.629028} & $X=1$ & 0.6290 & $40 \%$ \\
\hline & & $X=2$ & 1.2580 & $31 \%$ \\
\hline & & $X=3$ & 1.8870 & $24 \%$ \\
\hline \multirow{3}{*}{$\mathrm{F} 4$} & \multirow{3}{*}{0.380309} & $X=1$ & 0.3803 & $59 \%$ \\
\hline & & $X=2$ & 0.6814 & $68 \%$ \\
\hline & & $X=3$ & 1.1409 & $76 \%$ \\
\hline \multirow{3}{*}{ F5 } & \multirow{3}{*}{0.809717} & $X=1$ & 0.8097 & $69 \%$ \\
\hline & & $X=2$ & 1.6194 & $83 \%$ \\
\hline & & $X=3$ & 2.4291 & $92 \%$ \\
\hline \multirow{3}{*}{ F6 } & \multirow{3}{*}{0.852620} & $X=1$ & 0.8526 & $70 \%$ \\
\hline & & $X=2$ & 1.7052 & $85 \%$ \\
\hline & & $X=3$ & 2.5578 & $93 \%$ \\
\hline \multirow{3}{*}{ F7 } & \multirow{3}{*}{0.687710} & $X=1$ & 0.6877 & $67 \%$ \\
\hline & & $X=2$ & 1.3754 & $80 \%$ \\
\hline & & $X=3$ & 2.0631 & 895 \\
\hline \multirow{3}{*}{ F8 } & \multirow{3}{*}{1.384878} & $X=1$ & 0.9999 & $73 \%$ \\
\hline & & $X=2$ & 1.9980 & $88 \%$ \\
\hline & & $X=3$ & 2.9970 & $95 \%$ \\
\hline \multirow{3}{*}{ F9 } & \multirow{3}{*}{0.281206} & $X=1$ & 0.2812 & 575 \\
\hline & & $X=2$ & 0.5624 & $64 \%$ \\
\hline & & $X=3$ & 0.8436 & $70 \%$ \\
\hline \multirow{3}{*}{ F10 } & \multirow{3}{*}{0.637297} & $X=1$ & 0.6372 & $65 \%$ \\
\hline & & $X=2$ & 1.2745 & $78 \%$ \\
\hline & & $X=3$ & 0.8712 & $87 \%$ \\
\hline \multirow{3}{*}{ F11 } & \multirow{3}{*}{1.346561} & $X=1$ & 0.9990 & $73 \%$ \\
\hline & & $X=2$ & 1.9980 & $88 \%$ \\
\hline & & $X=3$ & 2.9970 & $95 \%$ \\
\hline
\end{tabular}

Fig. 2. Desertion probability when $\mathrm{X}=1$ 
The estimation results displayed in Figure 3 show that high coefficient values $(\beta)$ are related to high desertion probabilities. The Y estimates indicate that there is a causal relationship between the identified factors and university desertion. The proposed simulation model indicates that there is a $57 \%$ probability of university desertion. Factors such as number of students' children (F8) and students' perspectives on their integration into the labor market (F11) present higher probabilities of desertion. For the factor number of students' children, the value $(\beta)=1$ indicates that an increase in the number of students' children during university attendance increases thedesertion probability. Thus, if a student has one child, the desertion probability is $73 \%$.

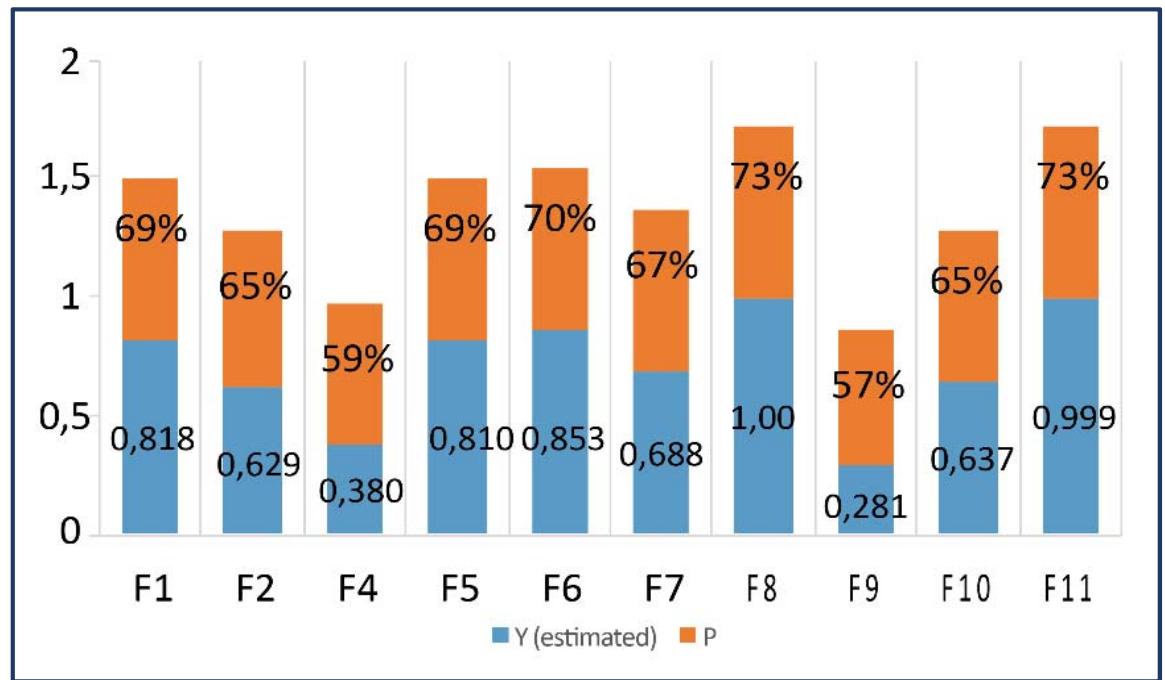

Fig. 3. Desertion probability when $\mathrm{X}=1$

The high influence of this factor in this model is explained by the fact that $53 \%$ of the students who answered this question were women and most respondents reported having at least one child. Therefore, the presence of children can generate lifestyle changes that reduce the probability of students successfully finishing their undergraduate studies.

The results for the factor students' perspectives on their integration into the labor market (F11)indicate a desertion probability of $73 \%$. One of the main objectives for the universities is to strengthen academic competencies that enable the development of professional capabilities so that students can integrate into the workforce. If a student believes that his/her university training is not contributing to his/her job prospects, he/she will find other higher education institutions that offer more suitable academic, technological and social facilities in terms of fulfilling work-related expectations.

On the other hand, Figure 4 shows that an increase in the estimate of $Y$ (when $X=3$ ) generates an increase in the desertion probability. When the factors are individually activated, the value of minimum probability is $70 \%$, while the maximum probability goes up to $95 \%$. Hence, there is a significant causal relationship between each of the identified factors and university desertion.Figure 5 shows that the factor of teacher's commitment to the student (F3) exhibits a negative value $(\beta)$. The results indicate that there is an inverse relationship between the constant and the factor. Hence, a decrease in the teacher's commitment to the students' academic and personal development increases the desertion probability by up to $40 \%$. 


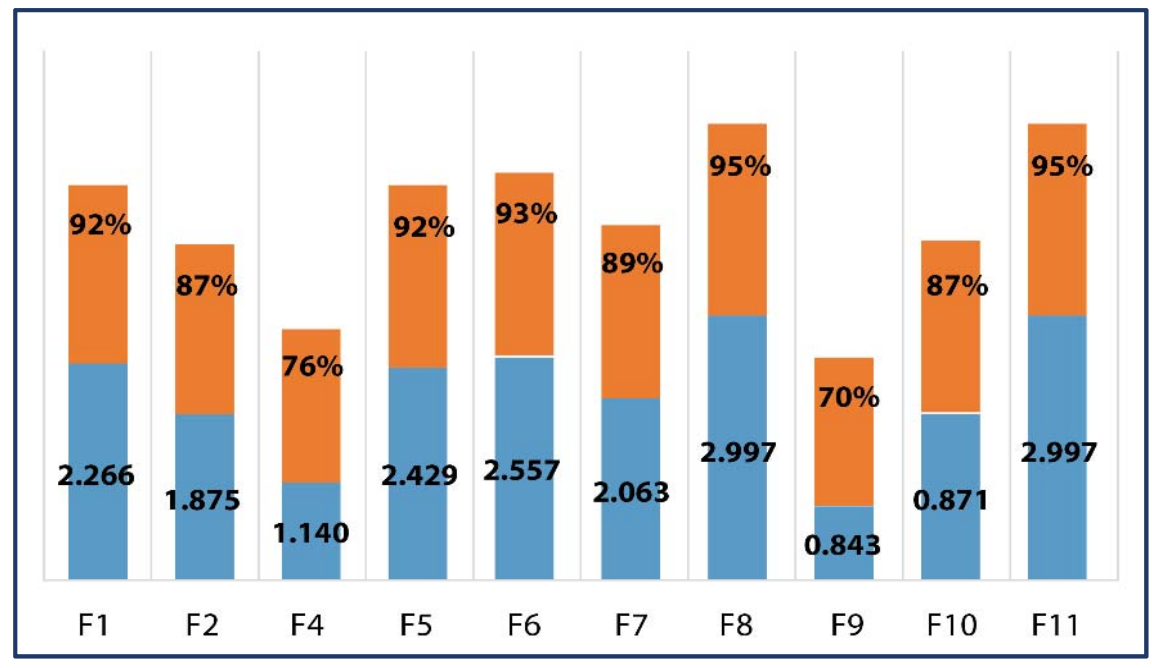

Fig. 4. Desertion probability when $\mathrm{X}=3$

Finally, when all the factors are activated at once with the smaller value $(X=1)$, the probability of a student opting to drop out of the university is $95 \%$, this shows the importance of the identified factors proposed in this study.

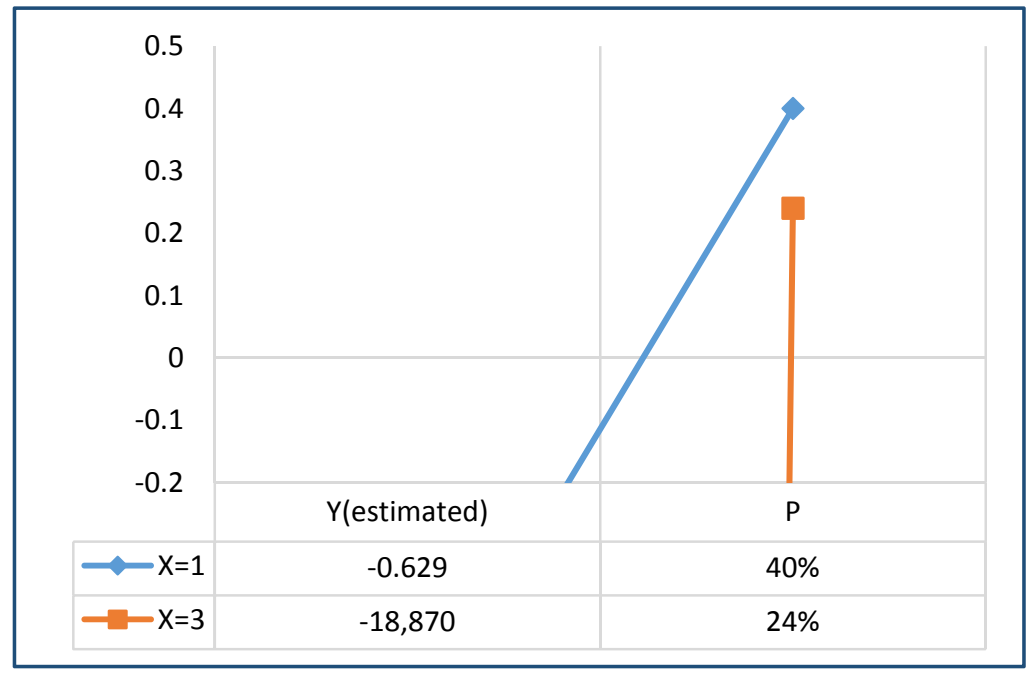

Fig. 5. Factor with negative value $(\beta)$

\section{Conclusions}

University desertion is influenced by various factors that negatively affect students' decisions to drop out of college. Taking this into consideration, the objective of the present work was to estimate the degree of influence for the factors of limited knowledge about specialized software usage in the university major, planned and unplanned pregnancy, teacher's commitment to the student, first-born son's financial commitment to his family, bullying, sexism, students' acquired addictions, students' numbers of children, students' adaptation to university learning methodologies, major or institution ranking, and students' perspectives on their integration into the labor market have on university desertion. Based on the methodology we applied, these 11 newly identified factors have a strong causal relationship with desertion. The results presented in this paper provide valuable information for decision-makersin higher education institutions.

Considering that most of the identified factors correspond to the students' personal circumstances, it is necessary to establish strategies that encourage links between students and universities that can increase students' welfare. With these strategies, students will have better chances of finishing their undergraduate studies, thereby reducing university desertion rates. 


\section{REFERENCES}

[1] C. Díaz Peralta, "Conceptual Model for dropout Chilean university student," Estudios pedagógicos (Valdivia), vol. 34, pp. 65-86, 2008.

[2] E. Castaño, S. Gallón, and J. Vásquez, " Analysis of the factors associated with student desertion in higher education: a case study " Revista de Education, pp. 255-280, 2008.

[3] E. Himmel, "Models of analysis of student desertion in higher education," Revista calidad de la educación, vol. 17, pp. 91-108, 2002.

[4] P. A. Willging and S. D. Johnson, "Factors that influence students' decision to dropout of online courses," Journal of Asynchronous Learning Networks, vol. 13, pp. 115-127, 2009.

[5] E. Hovdhaugen, "Transfer and dropout: Different forms of student departure in Norway," Studies in Higher Education, vol. 34, pp. 1$17,2009$.

[6] L. Gartner Isaza, C. Dussán Lubert, and D. M. Montoya, "Characterization of students' dropout at Universidad de CALDAS during the 2009-2013 period. Analysis from the dropout prevention system in higher education (DPSHE)," Revista Latinoamericana de Estudios Educativos (Colombia), vol. 12, 2016.

[7] L. Gitto, L. F. Minervini, and L. Monaco, "University dropouts in Italy: Are supply side characteristics part of the problem?," Economic Analysis and Policy, vol. 49, pp. 108-116, 2016.

[8] L. S. Stratton, D. M. O'Toole, and J. N. Wetzel, "A multinomial logit model of college stopout and dropout behavior," Economics of education review, vol. 27, pp. 319-331, 2008.

[9] L. D. O'Neill, M. K. Christensen, M. C. Vonsild, and B. Wallstedt, "Program specific admission testing and dropout for sports science students: a prospective cohort study," Dansk Universitetspædagogisk Tidsskrift, vol. 9, pp. 55-70, 2014.

[10] G. Sánchez, W. Navarro, and A. García, "Factores de deserción estudiantil en la Universidad Surcolombiana," Recuperado el, vol. 18, 2002.

[11] S. Human-Vogel and P. Rabe, "Measuring self-differentiation and academic commitment in University students: A case study of education and engineering students," South African Journal of Psychology, vol. 45, pp. 60-70, 2015.

[12] S. Sivakumar, S. Venkataraman, and R. Selvaraj, "Predictive modeling of student dropout indicators in educational data mining using improved decision tree," Indian Journal of Science and Technology, vol. 9, 2016.

[13] C. E. L. Guarín, E. L. Guzmán, and F. A. González, "A model to predict low academic performance at a specific enrollment using data mining," IEEE Revista Iberoamericana de tecnologias del Aprendizaje, vol. 10, pp. 119-125, 2015.

[14] P. Belo and C. Oliveira, "The Relation between Experiences and Expectations with University Dropout," Procedia-Social and Behavioral Sciences, vol. 187, pp. 98-101, 2015.

[15] E. Yukselturk, S. Ozekes, and Y. K. Türel, "Predicting dropout student: an application of data mining methods in an online education program," European Journal of Open, Distance and E-learning, vol. 17, pp. 118-133, 2014.

[16] J. Wray, D. Barrett, J. Aspland, and E. Gardiner, "Staying the course: Factors influencing pre-registration nursing student progression into Year 2-A retrospective cohort study," International Journal of Nursing Studies, vol. 49, pp. 1432-1442, 2012.

[17] M. Tan and P. Shao, "Prediction of student dropout in e-Learning program through the use of machine learning method," International Journal of Emerging Technologies in Learning (iJET), vol. 10, pp. 11-17, 2015.

[18] Y. Levy, "Comparing dropouts and persistence in e-learning courses," Computers \& education, vol. 48, pp. 185-204, 2007.

[19] F. Roso-Bas, A. P. Jiménez, and E. García-Buades, "Emotional variables, dropout and academic performance in Spanish nursing students," Nurse education today, vol. 37, pp. 53-58, 2016.

[20] J.-H. Park and H. J. Choi, "Factors influencing adult learners' decision to drop out or persist in online learning," Journal of Educational Technology \& Society, vol. 12, 2009.

[21] R. Chen and S. L. DesJardins, "Exploring the effects of financial aid on the gap in student dropout risks by income level," Research in higher education, vol. 49, pp. 1-18, 2008.

[22] S. Herzog, "Measuring determinants of student return vs. dropout/stopout vs. transfer: A first-to-second year analysis of new freshmen," Research in higher education, vol. 46, pp. 883-928, 2005.

[23] S. Tumen, B. Shulruf, and J. Hattie, "Student pathways at the university: Patterns and predictors of completion," Studies in Higher Education, vol. 33, pp. 233-252, 2008.

[24] A. Sangodiah, P. Beleya, M. Muniandy, L. E. Heng, and C. Ramendran SPR, "Minimizing Student Attrition in Higher Learning Institutions in Malaysia Using Support Vector Machine," Journal of Theoretical \& Applied Information Technology, vol. 71, 2015.

[25] V. R. Martinho, C. Nunes, and C. R. Minussi, "Prediction of school dropout risk group using Neural Network," in Computer science and information systems (FedCSIS), 2013 federated conference on, 2013, pp. 111-114.

[26] D. Heredia, Y. Amaya, and E. Barrientos, "Student dropout predictive model using data mining techniques," IEEE Latin America Transactions, vol. 13, pp. 3127-3134, 2015.

[27] W. Arulampalam, R. A. Naylor, and J. P. Smith, "Dropping out of medical school in the UK: explaining the changes over ten years," Medical Education, vol. 41, pp. 385-394, 2007.

[28] M. González-Flores, M. Heracleous, and P. Winters, "Leaving the safety net: an analysis of dropouts in an urban conditional cash transfer program," World Development, vol. 40, pp. 2505-2521, 2012.

[29] W. Arulampalam, R. A. Naylor, and J. P. Smith, "Effects of in-class variation and student rank on the probability of withdrawal: crosssection and time-series analysis for UK university students," Economics of Education Review, vol. 24, pp. 251-262, 2005.

[30] G. Di Pietro and A. Cutillo, "Degree flexibility and university drop-out: The Italian experience," Economics of Education Review, vol. 27, pp. 546-555, 2008.

[31] T. Melguizo, F. Sanchez, and T. Velasco, "Credit for low-income students and access to and academic performance in higher education in Colombia: A regression discontinuity approach," World development, vol. 80, pp. 61-77, 2016.

[32] A. Saranya and J. Rajeswari, "Enhanced Prediction of Student Dropouts Using Fuzzy Inference System and Logistic Regression," ICTACT Journal on Soft Computing, vol. 6, 2016.

[33] A.-S. Hoffait and M. Schyns, "Early detection of university students with potential difficulties," Decision Support Systems, vol. 101, pp. 1-11, 2017.

[34] N. Lam-On and T. Boongoen, "Using cluster ensemble to improve classification of student dropout in Thai university," in Soft Computing and Intelligent Systems (SCIS), 2014 Joint 7th International Conference on and Advanced Intelligent Systems (ISIS), 15th International Symposium on, 2014, pp. 452-457.

[35] A. L. Reschly and S. L. Christenson, "Prediction of dropout among students with mild disabilities: A case for the inclusion of student engagement variables," Remedial and Special Education, vol. 27, pp. 276-292, 2006.

[36] L. Willcoxson, J. Cotter, and S. Joy, "Beyond the first year experience: the impact on attrition of student experiences throughout undergraduate degree studies in six diverse universities," Studies in Higher Education, vol. 36, pp. 331-352, 2011.

[37] D. Thammasiri, D. Delen, P. Meesad, and N. Kasap, "A critical assessment of imbalanced class distribution problem: The case of predicting freshmen student attrition," Expert Systems with Applications, vol. 41, pp. 321-330, 2014. 
[38] L. Oseguera and B. S. Rhee, "The influence of institutional retention climates on student persistence to degree completion: A multilevel approach," Research in Higher Education, vol. 50, pp. 546-569, 2009.

[39] D. Yasmin, "Application of the classification tree model in predicting learner dropout behaviour in open and distance learning," Distance Education, vol. 34, pp. 218-231, 2013.

[40] H. Yi, L. Zhang, Y. Yao, A. Wang, Y. Ma, Y. Shi, et al., "Exploring the dropout rates and causes of dropout in upper-secondary technical and vocational education and training (TVET) schools in China," International Journal of Educational Development, vol. 42, pp. 115-123, 2015.

[41] S. Natek and M. Zwilling, "Student data mining solution-knowledge management system related to higher education institutions," Expert systems with applications, vol. 41, pp. 6400-6407, 2014.

[42] L. Paura and I. Arhipova, "Cause analysis of students' dropout rate in higher education study program," Procedia-Social and Behavioral Sciences, vol. 109, pp. 1282-1286, 2014.

[43] I. Lykourentzou, I. Giannoukos, V. Nikolopoulos, G. Mpardis, and V. Loumos, "Dropout prediction in e-learning courses through the combination of machine learning techniques," Computers \& Education, vol. 53, pp. 950-965, 2009.

[44] M. Jadrić, Ž. Garača, and M. Čukušić, "Student dropout analysis with application of data mining methods," Management: journal of contemporary management issues, vol. 15, pp. 31-46, 2010.

[45] S. Sultana, S. Khan, and M. A. Abbas, "Predicting performance of electrical engineering students using cognitive and non-cognitive features for identification of potential dropouts," International Journal of Electrical Engineering Education, vol. 54, pp. 105-118, 2017.

[46] E. F. Iepsen, M. Bercht, and E. Reategui, "Detection and assistance to students who show frustration in learning of algorithms," in Frontiers in Education Conference, 2013 IEEE, 2013, pp. 1183-1189.

[47] M. H. Arifin, "Exploring factors in contributing student progress in the Open University," International Journal of Information and Education Technology, vol. 6, p. 29, 2016.

[48] S. Human-Vogel and P. Rabe, "Measuring self-differentiation and academic commitment in University students: A case study of education and engineering students," South African Journal of Psychology, vol. 45, pp. 60-70, 2015.

[49] N. Alkan, "Humor, loneliness and acceptance: Predictors of university drop-out intentions," Procedia-Social and Behavioral Sciences, vol. 152, pp. 1079-1086, 2014.

[50] R. Duarte, A. Ramos-Pires, and H. Gonçalves, "Identifying at-risk students in higher education," Quality control and applied statistics, vol. 60 , pp. 557-558, 2015.

[51] L. C. Duque, "A framework for analysing higher education performance: students' satisfaction, perceived learning outcomes, and dropout intentions," Total Quality Management \& Business Excellence, vol. 25, pp. 1-21, 2014.

[52] P. Belo and C. Oliveira, "The Relation between Experiences and Expectations with University Dropout," Procedia-Social and Behavioral Sciences, vol. 187, pp. 98-101, 2015.

[53] J. Bayer, H. Bydzovská, J. Géryk, T. Obsivac, and L. Popelinsky, "Predicting Drop-Out from Social Behaviour of Students," International Educational Data Mining Society, 2012.

[54] M. A. Al-barrak and M. S. Al-Razgan, "Predicting Students Performance through Classification: A Case Study," Journal of Theoretical \& Applied Information Technology, vol. 75, 2015.

[55] S.-H. Lin, "Data mining for student retention management," Journal of Computing Sciences in Colleges, vol. 27, pp. 92-99, 2012.

[56] P. Jia and T. Maloney, "Using predictive modelling to identify students at risk of poor university outcomes," Higher Education, vol. 70, pp. 127-149, 2015.

[57] L. Aulck, N. Velagapudi, J. Blumenstock, and J. West, "Predicting student dropout in higher education," arXiv preprint arXiv: $1606.06364,2016$.

[58] S. Huang and N. Fang, "Predicting student academic performance in an engineering dynamics course: A comparison of four types of predictive mathematical models," Computers \& Education, vol. 61, pp. 133-145, 2013.

[59] D. A. Koonce and D. A. Hening, "Data Imputation to Identify Potential Dropouts," in IIE Annual Conference. Proceedings, 2009, p. 246.

[60] R. Chen, "Institutional characteristics and college student dropout risks: A multilevel event history analysis," Research in Higher Education, vol. 53, pp. 487-505, 2012.

[61] M. Ćukušić, Ž. Garača, and M. Jadrić, "Online self-assessment and students' success in higher education institutions," Computers \& Education, vol. 72, pp. 100-109, 2014.

[62] W. Xing, X. Chen, J. Stein, and M. Marcinkowski, "Temporal predication of dropouts in MOOCs: Reaching the low hanging fruit through stacking generalization," Computers in Human Behavior, vol. 58, pp. 119-129, 2016.

[63] G. M. Martín, R. M. Martínez, M. M. Martín, M. I. F. Nieto, and S. V. G. Núñez, "Acercamiento a las Teorías del Aprendizaje en la Educación Superior," UNIANDES EPISTEME, vol. 4, pp. 48-60, 2017.

[64] N. Taffa and F. Obare, "Pregnancy and child health outcomes among adolescents in Ethiopia," The Ethiopian Journal of Health Development (EJHD), vol. 18, 2017.

[65] T. Mueller, H. D. Tevendale, T. R. Fuller, L. D. House, L. M. Romero, A. Brittain, et al., "Teen pregnancy prevention: Implementation of a multicomponent, community-wide approach," Journal of Adolescent Health, vol. 60, pp. S9-S17, 2017.

[66] A. Y. Black, N. A. Fleming, and E. S. Rome, "Pregnancy in adolescents," Adolescent medicine: State of the art reviews, vol. 23, pp. 123-38, xi, 2012.

[67] P. Hallinger, R. Hosseingholizadeh, N. Hashemi, and M. Kouhsari, "Do beliefs make a difference? Exploring how principal selfefficacy and instructional leadership impact teacher efficacy and commitment in Iran," Educational Management Administration \& Leadership, p. 1741143217700283, 2017.

[68] A. B. L. Miranda, "Academic excellence indicators, the perspective of posgraduate students," Journal for Educators, Teachers and Trainers, vol. 8, 2017.

[69] T. Ito, "Caste discrimination and transaction costs in the labor market: Evidence from rural North India," Journal of development Economics, vol. 88, pp. 292-300, 2009.

[70] W. h. Yu and K. h. Su, "Gender, sibship structure, and educational inequality in Taiwan: Son preference revisited," Journal of Marriage and Family, vol. 68, pp. 1057-1068, 2006.

[71] W. A. Leal Rodríguez and H. A. Torrealba Ratia, "motivational actors an integrative approach in the academic performance of the subject office administration in the mention: education for work sub-commercial area of the Faculty of Education Sciences at the University of Carabobo," 2017.

[72] A. J. Rojas Luque, "Comprehensive behavior and school bullying in high school students," 2013.

[73] R. A. Dueñas and M. J. R. Valdivia, "BULLYNG Y PODER," Investigación Valdizana, vol. 10, pp. 119-122, 2017.

[74] S. I. Di Domenico and R. M. Ryan, "Commentary: Primary Emotional Systems and Personality: An Evolutionary Perspective," Frontiers in psychology, vol. 8, p. 1414, 2017. 
[75] N. B. Garrido, "Student desertion in the Master in University Teaching for first-year students," Análisis de la Realidad Nacional, vol. 102, p. 44, 2016.

[76] K. P. Jantke and S. Drefahl, "Theory of Mind Modeling and Induction: Ausdrucksfähigkeit und Reichweite," 2016.

[77] J. Rodríguez Vignoli, "Reproducción en la adolescencia: el caso de Chile y sus implicaciones de política," Revista de la CEPAL, 2005.

[78] A. Yoguez Seoane, "i How world-class universities are evaluated?. "Revista de la educación superior, vol. 38, pp. 113-120, 2009.

[79] C. Giannoulis and A. Ishizaka, "A Web-based decision support system with ELECTRE III for a personalised ranking of British universities," Decision Support Systems, vol. 48, pp. 488-497, 2010.

[80] M. García-Blanco and E. B. C. Sempértegui, "The Labor Insertion in Higher Education. The Latin American Perspective" Educación XX1, vol. 21, 2018.

[81] J. Navarro Cendejas, The Labor Insertion in Higher Education. TheLatin American Perspective: Universitat Autònoma de Barcelona, 2014.

[82] D. Gujarati and D. Porter, "Econometric (quinta edición)," Ed: México: McGRAW-HILL/Interamericana Editores, SS DE CV, 2010.

[83] M. del Carmen Ibarra and J. C. Michalus, "Analysis of academic performance using a Logit model," Revista Ingeniería Industrial, vol. 9, 2010.

[84] J. D. Canary, L. Blizzard, R. P. Barry, D. W. Hosmer, and S. J. Quinn, "A comparison of the Hosmer-Lemeshow, Pigeon-Heyse, and Tsiatis goodness-of-fit tests for binary logistic regression under two grouping methods," Communications in Statistics-Simulation and Computation, vol. 46, pp. 1871-1894, 2017.

\section{AUTHOR PROFILE}

Mayra AlbanShe earned a degree in Computer Science and Computational Systems from the Technical University of Cotopaxi, Ecuador, in 2002 along with a master's degree in Production Management in 2006 and a student of PhD at the National University of San Marcos in Lima, Peru. She is a professor of Computer Science and Computational Systems on the Department of Engineering and Applied Sciences at the Technical University of Cotopaxi. Currently, she is the director of the Information Systems major. Over the past five years, she has conducted research related to the students' university desertion and data mining. Profile about the first author of the manuscript should be updated here.

David Mauricio He earned a Doctor of Science degree in Systems Engineering and Computing (1991-1994) and a Master of Science degree in Applied Mathematics (1989-1991) from the Federal University of Rio de Janeiro, Brazil as well as a Bachelor of Computing degree from the National University of San Marcos. He was a professor at the North Fluminense State University of Brazil from 1994 to 1998. Since 1998, he has been a professor at the National University of San Marcos. Areas of interest: Combinatorial optimization, Design and analysis of algorithms, Heuristic search, Metaheuristics, Mathematical programming, Expert systems, Data mining, Artificial intelligence. 